\title{
Influence of Sector, Budget Size and Financing on Time and Cost Management of Czech International Development Projects
}

\author{
Gabriela Dufková ${ }^{1, *}$, Stanislav Šroch ${ }^{1}$ \\ ${ }^{1}$ University of Economics in Prague, Faculty of International Relations, Department of World \\ Economy, nám. Winstona Churchila 1938/4, 13067 Praha 3 - Žižkov, Czech Republic
}

\begin{abstract}
.
Research background: This article focuses on the official Czech international development (ID) aid and the factors affecting the project success in terms of cost and time variance from the plan. As per research by Ahsan and Gunawan (2010), ID projects by Asian Development Bank are finalised within their budget, however, with delays, and the result depends on the developing country. Previous article written by the author confirmed the findings also for the Czech development aid and established that cost variance is affected by the type of implementing agencies, whereas time variance depends on the developing countries.

Purpose of the article: The purpose of this article is to further analyse ID projects by the Czech Development Agency and evaluate the influence of sector topics, budget size and type of financing on the time and budget management of Czech ID projects to determine what parameters could improve the efficiency of Czech ID projects.

Methods: Information on all official projects conducted from 2016 to 2019 used in this article are non-public and have been received directly from the Czech Development Agency. They are first summarised in a descriptive statistics part and then analysed by non-parametric Kruskal-Wallis test.

Findings \& Value added: The results show that budget size, financing type and sector topics influence the cost variance, with smaller projects financed as public procurement achieving bigger savings. For time variance, there are significant differences only between different categories of the sector topics with projects focused on the environment leading to the biggest delays.
\end{abstract}

Keywords: international development projects; official Czech development aid; cost variance; time variance; project success

JEL Classification: $O 00 ; O 01 ; C 14$

\footnotetext{
* Corresponding author: xdufg00@vse.cz
} 


\section{Introduction}

The Czech Republic spends annually around $0.13 \%$ of GNI on development aid (OECD, 2019). As its international development projects are funded by public money, a focus is paid on their results. Existing research (Ahsan and Gunawan (2010), Kaimasu et al. (2017)) suggests that ID projects are generally finished within their budget, but with schedule overruns. This study therefore aims to estimate what project characteristics may influence the time and cost variance of the ID projects in order to improve the efficiency of development aid.

Previous research has shown that the cost variance is affected by the type of implementing agency, while the time variance by developing countries. This article focuses on three other factors that can influence time and cost variance of the official Czech development projects, i.e. sector, budget size and financing. The article is divided into three parts, the first chapter describes the methodology used, the second chapter presents the results of both descriptive statistics and Kruskal-Wallis test and discussion is held in the last part. The second chapter is organised into three sub-chapters, one for each factor.

\section{Methodology}

This research is methodologically inspired by Ahsan and Gunawan (2010) and their analysis of cost and time variance of Asian development bank projects. In this article, Kruskal-Wallis test is used to determine the influence of the researched variables on cost and time management of Czech ID projects. Used data are non-public and were received directly from the Czech Development Agency upon request and contained information on all projects from 2016 to 2019 such as the project name, implementing agency, receiving country, sector, financing type, planned and final yearly budget, and planned and final total duration. The analysis was conducted in SPSS software.

The explanation of research variables is presented in Table 1 below.

Table 1. Research variables.

\begin{tabular}{|c|c|c|}
\hline $\begin{array}{c}\text { Dependent } \\
\text { variable }\end{array}$ & Measurement & Source \\
\hline Cost variance & Difference between planned and final yearly budget & ČRA \\
\hline Time variance & Difference between planned and final total duration of the project & ČRA \\
\hline $\begin{array}{c}\text { Independent } \\
\text { variable }\end{array}$ & Category & Source \\
\hline Sector & $\begin{array}{c}\text { Water, agriculture, energy, state administration, healthcare, } \\
\text { education, social, forestry, catastrophes, mining, environment }\end{array}$ & ČRA \\
\hline Financing & $\begin{array}{c}\text { Public procurement, grant (project), grant title, project, budgetary } \\
\text { measure, sector topic }\end{array}$ & ČRA \\
\hline Budget size & $\begin{array}{c}\text { Small (up to 1m CZK incl.), middle (1m CZK up to 4 m CZK } \\
\text { incl.), big (more than 4m CZK) }\end{array}$ & ČRA \\
\hline
\end{tabular}

The research questions of this article are as follows:

- Is cost variance of Czech ID projects influenced by sector, financing and/or budget size?

- Is time variance of Czech ID projects influenced by sector, financing and/or budget size? 


\section{Results}

\subsection{Sector and its influence on cost and time variance of Czech ID projects}

Czech development projects are implemented in 11 sectors with the most common being agriculture (21\%), state administration (16\%) and social topics $(10 \%)$. The number of projects in each sector and the percentage share of the sector on the total is shown in figure 1 below.

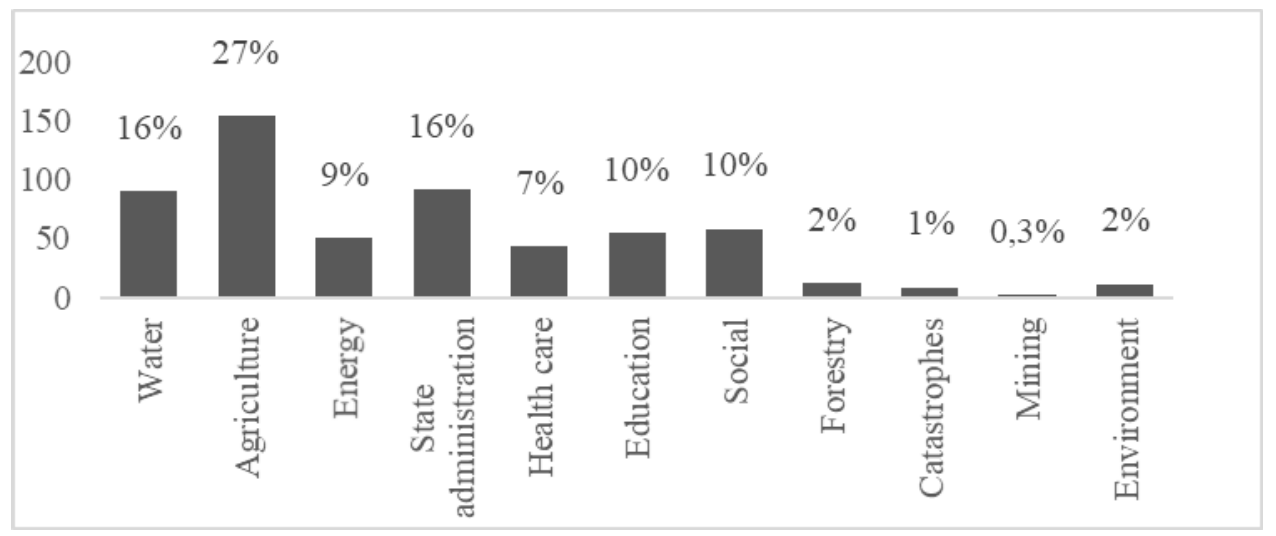

Fig. 1. Number of projects in each sector and the percentage share of the sector on total

The largest projects in terms of money were projects in mining $(9,475,985 \mathrm{CZK}$ in average), forestry $(3,336,482 \mathrm{CZK})$ and water $(3,086,142 \mathrm{CZK})$. On the other hand, the smallest projects were implemented in the catastrophes sector $(683,863 \mathrm{CZK})$ and environment $(1,885,369 \mathrm{CZK})$. Projects in all sectors were generally finished within the budget. The mean planned and final budget for each sector is shown in table 2 below.

As for the average duration of the projects, the longest projects were implemented in environment (3.4 years) and forestry (3.1 years) while the shortest were in energy (2.2 years) and health care (2.2 years). Projects were mostly finished on time with the greatest delay of half year in the environment sector. The mean planned and final duration for each sector is shown in table 2 below.

Table 2. Sector: cost and time variance.

\begin{tabular}{|c|c|c|c|c|c|}
\hline Sector & $\begin{array}{c}\text { \# of } \\
\text { projects }\end{array}$ & $\begin{array}{c}\text { Mean planned } \\
\text { budget (CZK) }\end{array}$ & $\begin{array}{c}\text { Mean final } \\
\text { budget } \\
\text { (CZK) }\end{array}$ & $\begin{array}{c}\text { Mean planned } \\
\text { duration } \\
\text { (years) }\end{array}$ & $\begin{array}{c}\text { Mean final } \\
\text { duration } \\
\text { (years) }\end{array}$ \\
\hline Water & 90 & $3,086,142$ & $2,538,286$ & 2.7 & 2.7 \\
\hline Agriculture & 154 & $2,279,842$ & $2,126,662$ & 2.8 & 3.0 \\
\hline Energy & 50 & $2,160,929$ & $1,742,298$ & 2.2 & 2.4 \\
\hline $\begin{array}{c}\text { State } \\
\text { administration }\end{array}$ & 92 & $2,057,449$ & $1,923,480$ & 2.6 & 2.7 \\
\hline Health care & 43 & $2,627,772$ & $2,220,207$ & 2.2 & 2.3 \\
\hline Education & 55 & $2,380,173$ & $2,228,073$ & 2.3 & 2.4 \\
\hline Social & 58 & $2,634,952$ & $2,552,768$ & 2.3 & 2.3 \\
\hline Forestry & 12 & $3,336,482$ & $3,336,482$ & 3.1 & 3.3 \\
\hline Catastrophes & 8 & 683,863 & 683,863 & 2.8 & 3.1 \\
\hline
\end{tabular}




\begin{tabular}{|c|c|c|c|c|c|}
\hline Mining & 2 & $9,475,985$ & $9,305,985$ & 2.5 & 2.5 \\
\hline Environment & 11 & $1,885,369$ & $1,864,281$ & 3.4 & 3.9 \\
\hline Total & 575 & $2,448,888$ & $2,209,962$ & 2.6 & 2.7 \\
\hline
\end{tabular}

The non-parametric Kruskal-Wallis test was conducted for cost variance and showed that at $5 \%$ level of significance there was a statistically significant difference in cost variance between the different sectors, $\chi 2(2)=30.376, p=0.001$, as presented in table 3 below and a mean rank in appendix.

The same test was also conducted for time variance and showed that at $5 \%$ level of significance there was a statistically significant difference in time variance between the different sectors, $\chi 2(2)=20.096, p=0.028$, as presented in table 3 and a mean rank in table 4 below.

Table 3. Sector: Kruskal-Wallis test on cost and time variance.

\begin{tabular}{|c|c|c|}
\hline & Cost management & Time management \\
\hline Kruskal-Wallis H & 30.376 & 20.096 \\
\hline Df & 10 & 10 \\
\hline Asymp. Sig. & 0.001 & 0.028 \\
\hline
\end{tabular}

Table 4. Sector: Mean Rank

\begin{tabular}{|c|c|c|}
\hline Sector & $\begin{array}{c}\text { \# of } \\
\text { projects }\end{array}$ & Mean Rank \\
\hline Water & 90 & 281.88 \\
\hline Agriculture & 154 & 280.27 \\
\hline Energy & 50 & 216.76 \\
\hline $\begin{array}{c}\text { State } \\
\text { administration }\end{array}$ & 92 & 319.64 \\
\hline Health care & 43 & 252.95 \\
\hline Education & 55 & 293.60 \\
\hline Social & 58 & 324.07 \\
\hline Forestry & 12 & 359.00 \\
\hline Catastrophes & 8 & 359.00 \\
\hline Mining & 2 & 202.50 \\
\hline Environment & 11 & 310.73 \\
\hline Total & 575 & \\
\hline
\end{tabular}

From the results of Kruskal-Wallis test we therefore assume that sector may influence both cost and time management of Czech international development projects.

\subsection{Financing and its influence on cost and time variance of ID projects}

Czech development agency finances its projects in various ways, with the majority of projects being financed as public procurement (53\%) and grants $(29 \%)$. The number of projects in each financing type and the percentage share of the financing type on the total is shown in figure 2 below. 


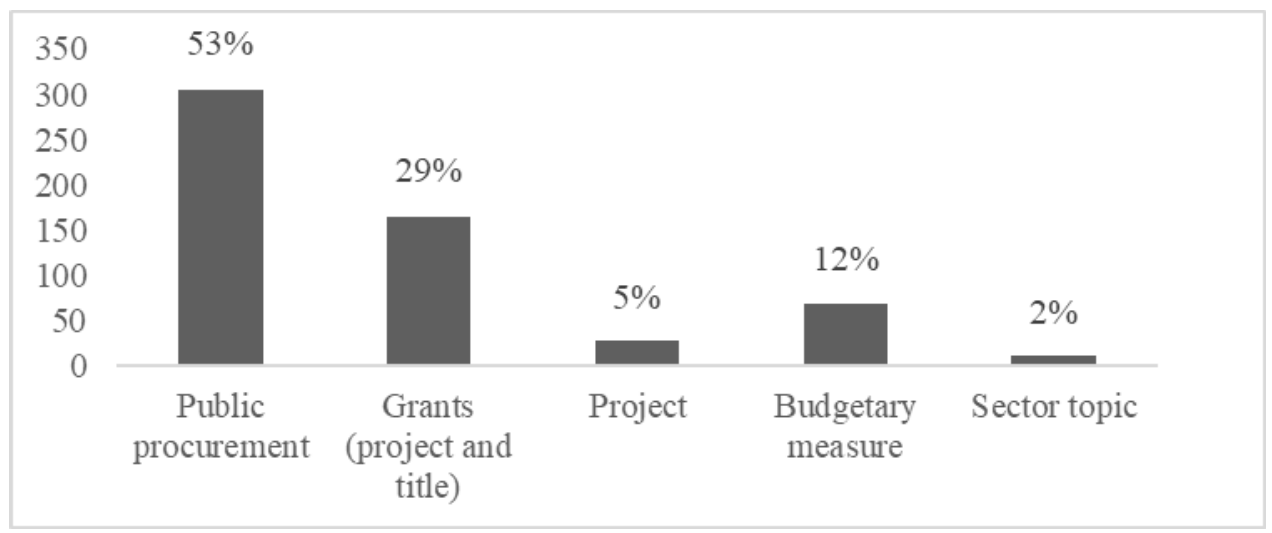

Fig. 2. Number of projects for each type of financing and the percentage share on total.

The largest projects in terms of money were finance as grants $(3,388,572$ CZK in average), on the other hand, the smallest projects were financed as a budgetary measure $(2,035,907 \mathrm{CZK})$. Projects with all financing types were generally finished within the budget with the biggest savings from the planned budget being achieved in public procurement. Projects financed by all types were generally finished within the budget. The mean planned and final budget for each financing type is shown in table 4 below.

As for the average duration of the projects, the longest projects were implemented as budgetary measures (3.5 years), the shortest in average as public procurement. Projects were finished with delays in most of the financing types with the greatest delays in budgetary measures. The mean planned and final duration for each financing type is shown in table 5 below.

Table 5. Financing type: cost and time variance.

\begin{tabular}{|c|c|c|c|c|c|}
\hline Financing & $\begin{array}{c}\text { Number } \\
\text { of } \\
\text { projects }\end{array}$ & $\begin{array}{c}\text { Mean planned } \\
\text { budget (CZK) }\end{array}$ & $\begin{array}{c}\text { Mean final } \\
\text { budget } \\
\text { (CZK) }\end{array}$ & $\begin{array}{c}\text { Mean planned } \\
\text { duration } \\
\text { (years) }\end{array}$ & $\begin{array}{c}\text { Mean final } \\
\text { duration } \\
\text { (years) }\end{array}$ \\
\hline $\begin{array}{c}\text { Public } \\
\text { procurement }\end{array}$ & 304 & $2,054,656$ & $1,671,814$ & 2.2 & 2.4 \\
\hline $\begin{array}{c}\text { Grants } \\
\text { projects } \\
\text { and title) }\end{array}$ & 164 & $3,388,572$ & $3,306,365$ & 2.9 & 3.0 \\
\hline Project & 27 & $2,336,966$ & $2,124,354$ & 2.3 & 2.3 \\
\hline $\begin{array}{c}\text { Budgetary } \\
\text { measure }\end{array}$ & 69 & $2,035,907$ & $2,013,046$ & 3.5 & 3.8 \\
\hline Sector topic & 11 & $2,199,452$ & $2,181,348$ & 2.4 & 2.4 \\
\hline Total & 575 & $2,448,888$ & $2,209,962$ & 2.6 & 2.70 \\
\hline
\end{tabular}

The non-parametric Kruskal-Wallis test was conducted here as well to establish whether the way of financing influences the cost and time variance. The results for cost variance show that at $5 \%$ level of significance there was a statistically significant difference in cost variance between the different financing ways, $\chi 2(2)=59.771, p=0.000$, as presented in table 5 below and the mean rank in appendix. 
As for time variance, there was not, at 5\% level of significance, a statistically significant difference between the different financing ways, $\chi 2(2)=3.449, p=0.178$ as shown in table 6 and with a mean rank as presented in table 7 below.

Table 6. Financing type: Kruskal-Wallis test on cost and time variance.

\begin{tabular}{|c|c|c|}
\hline & Cost management & Time management \\
\hline Kruskal-Wallis H & 59.771 & 3.449 \\
\hline Df & 2 & 2 \\
\hline Asymp. Sig. & 0.000 & 0.178 \\
\hline
\end{tabular}

Table 7. Financing type: Mean ranks

\begin{tabular}{|c|c|c|}
\hline Financing & $\begin{array}{c}\text { Number } \\
\text { of } \\
\text { projects }\end{array}$ & Mean Rank \\
\hline $\begin{array}{c}\text { Public } \\
\text { procurement }\end{array}$ & 304 & 288.09 \\
\hline $\begin{array}{c}\text { Grants } \\
\text { (projects and } \\
\text { title) }\end{array}$ & 164 & 279.76 \\
\hline Other & 107 & 300.38 \\
\hline Total & 575 & \\
\hline
\end{tabular}

Based on the results above, we may assume that projects implemented under different financing may achieve different cost variance, however, financing will not influence the time variance.

\subsection{Budget size and its influence on cost and time variance of ID projects}

In the last sub-chapter, the influence of the budget size on cost and time variance was analysed. For the purpose of this research the projects were divided into three categories: small (up to $1 \mathrm{~m} \mathrm{CZK}$ incl.), middle ( $1 \mathrm{~m} \mathrm{CZK}$ up to $4 \mathrm{~m} \mathrm{CZK} \mathrm{incl.),} \mathrm{big} \mathrm{(more} \mathrm{than} 4 \mathrm{~m}$ CZK), with the most common being small projects (44\%). The number of projects in each group and the percentage share of the group on the total is shown in figure 3 below.

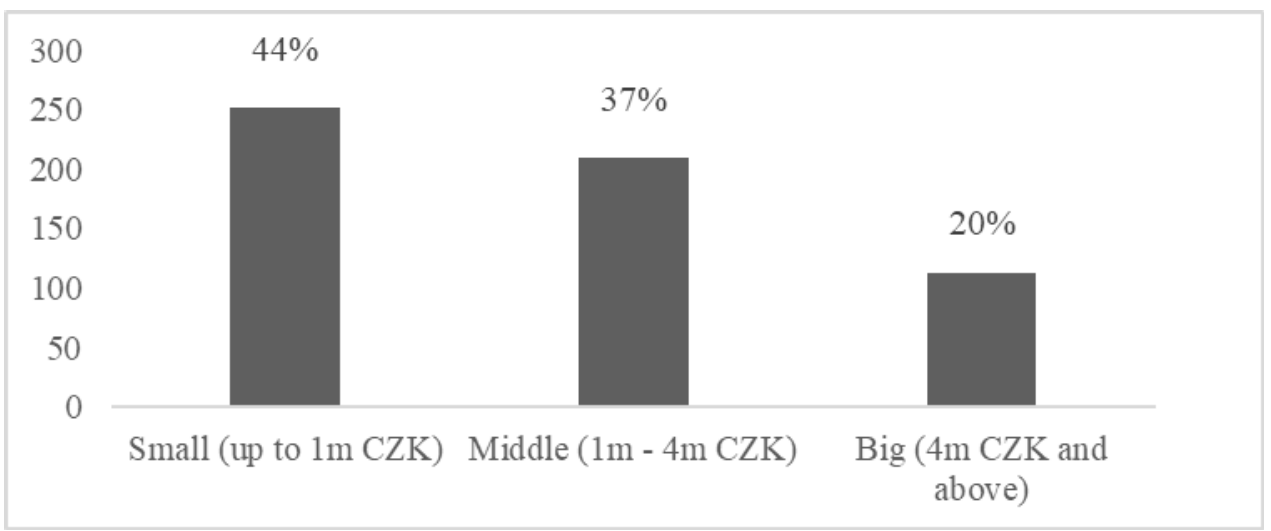

Fig. 3. Number of projects in budget size groups and the percentage share of the groups on total

Projects with the small budgets achieved proportionally the highest savings (14\% of the original budgets), however, they were also prolonged the most. The smallest savings and 
delays were achieved in the group of middle size projects. Cost and time variance of the budget groups is presented in table 8 below.

Table 8. Budget size: cost and time variance.

\begin{tabular}{|c|c|c|c|c|c|}
\hline $\begin{array}{c}\text { Budget } \\
\text { size }\end{array}$ & $\begin{array}{c}\text { Number } \\
\text { of } \\
\text { projects }\end{array}$ & $\begin{array}{c}\text { Mean planned } \\
\text { budget (CZK) }\end{array}$ & $\begin{array}{c}\text { Mean final } \\
\text { budget (CZK) }\end{array}$ & $\begin{array}{c}\text { Mean planned } \\
\text { duration } \\
\text { (years) }\end{array}$ & $\begin{array}{c}\text { Mean final } \\
\text { duration } \\
\text { (years) }\end{array}$ \\
\hline $\begin{array}{c}\text { Small } \\
\text { projects }\end{array}$ & 252 & 364,661 & 312,848 & 2.1 & 2.3 \\
\hline $\begin{array}{c}\text { Middle } \\
\text { projects }\end{array}$ & 210 & $2,297,680$ & $2,212,715$ & 2.8 & 2.9 \\
\hline $\begin{array}{c}\text { Big } \\
\text { projects }\end{array}$ & 113 & $7,377,906$ & $6,435,577$ & 3.0 & 3.2 \\
\hline Total & 575 & $2,448,888$ & $2,209,962$ & 2.6 & 2.7 \\
\hline
\end{tabular}

The non-parametric Kruskal-Wallis test was conducted here as well to establish whether the budget size influences the cost and time variance. Kruskal-Wallis test indicates that at $5 \%$ level of significance there was a statistically significant difference in cost variance between the different budget sizes, $\chi 2(2)=9.792, p=0.007$, as presented in table 6 below and mean ranks in appendix.

However, as for time variance, there was not at 5\% of significance a statistically significant difference between the different budget sizes, $\chi 2(2)=5.768, p=0.056$, as presented in table 9 and with mean ranks as shown in table 10 below.

Table 9. Financing type: Kruskal-Wallis test on cost and time variance.

\begin{tabular}{|c|c|c|}
\hline & Cost management & Time management \\
\hline Kruskal-Wallis H & 9.792 & 5.768 \\
\hline Df & 2 & 2 \\
\hline Asymp. Sig. & 0.007 & 0.0056 \\
\hline
\end{tabular}

Table 10. Budget size: Mean ranks

\begin{tabular}{|c|c|c|}
\hline Financing & $\begin{array}{c}\text { Number } \\
\text { of } \\
\text { projects }\end{array}$ & Mean Rank \\
\hline Small projects & 252 & 274.55 \\
\hline $\begin{array}{c}\text { Middle } \\
\text { projects }\end{array}$ & 210 & 312.35 \\
\hline Big projects & 113 & 272.73 \\
\hline Total & 575 & \\
\hline
\end{tabular}

\section{Discussion}

The analysis confirmed findings of Ahsan and Gunawan (2010) and Kaimasu et al. (2017) that ID projects are generally finished without cost overruns but with delays. The reason why Czech ID projects are mostly finished within the budget may be thanks to close monitoring from the ČRA's side and its financing policy: the financing is done on yearly basis and is conditional upon the evaluation of the achieved results with project managers reporting to ČRA throughout the whole duration of the project. This supports the findings of existing literature (Diallo and Thuillier (2004), Yamin and Sim (2016), Ika (2015)) that monitoring is one of the critical success factors for ID projects. 
The analysis furthermore showed that cost variance of ID projects is influenced by project sector, type of financing and the budget size. There might be various explanations for this finding. Locateli et al. (2017) suggests, that budget size and project sector can be interdependent, because project performance of big projects in developing countries is often undermined by corruption that influences the decision what is going to be undertaken and where. Another explanation for budget size influencing the cost variance is the higher complexity of bigger projects. The explanation of project sector is discussed later together with time variance. As for explanation why financing type influences budget, there was no discussion found in the literature and will therefore be part of the next research.

Time variance is - from the analysed factors - influenced only by the project sector. ČRA stated that their projects were delayed due to bad safety situation in the receiving country, natural disasters, low co-operation of local authorities or partners etc. Some of the projects are prolonged thanks to its outstanding contribution to the region and the decision of ČRA to finance them above their original timeframe. A question whether these reasons are sector-specific would require further research.

The analysis on time variance furthermore showed that ID projects were in general finished with delays regardless of their size, which confirms the findings of Kaimasu et al. (2017) of the existence of a paradox of project scale and delays.

As per the results presented above, project sector influences both cost and time variance of ID projects. As suggested by literature (Ahbab (2019)), projects involving construction and engineering are often prone to time and cost deviation. An additional analysis of the source data was therefore conducted to assess whether the delayed projects were of technical nature. Based on the analysis, two thirds of the projects that finished with time overrun involved installation of equipment, construction supervision etc. while only one third was of non-technical nature (education, care of mother and child etc.) thus confirming the findings of the existing literature.

The project success with regard to cost and time performance of the Czech ID projects in general might be improved by the application of relevant project management tools and methodologies by the implementing agencies. As existing literature (Matos et al. (2019), Golini et al (2015), Czahajda (2018), Ika et al (2012), Montes-Guerra et al. (2015)) suggests, projects that were implemented with the use of project management methodologies achieved in general better results than those without it. In spite of this fact, the application of project methodologies is not wide among non-governmental organisations: Czahajda (2019) estimates that only 18\% of Polish managers make use of any project methodology and Keleckaite and Meiliene (2015) suggest that the percentage might be higher for Lithuania with $58 \%$ of project managers using project management tools.

Next research could focus on the influence of the number of parties involved in the project (implementing agencies, contractors, local authorities etc.) on the cost and time variance - as Ceric (2014) suggests each party in the project is guided by self-interest, so the more parties are involved, the higher the chances are that the co-operation will cause damage to the aim of the project owner and sponsor.

\section{Conclusion}

This article focused on the official Czech international development projects with the goal to determine what project aspects may influence the cost and time variance of the ID projects. It analysed three factors, i.e. project sector, financing type and budget size. Based on the results, the cost variance of ID projects is influenced by project sector, type of financing and the budget size, whereas time variance is influenced only by the project sector. 
As ID projects are usually finished within the budget but with a time over-run, the literature suggests that the use of project methodologies might improve the overall project performance.

This paper was written with the support of IGA project called "Case studies in developing countries approach comparison of natural resource management and project management of development aid, no. F2/6/2020, University of Economics in Prague.

\section{References}

1. OECD (2019). Official Development Assistance (ODA). Retrieved from : https://www.oecd.org/dac/financing-sustainable-development/development-financestandards/official-development-assistance.htm

2. Ahsan, K., Gunawan, I. (2010). Analysis of cost and schedule performance of international development projects. International Journal of Project Management, 28(1), 68-78.

3. Kaimasu, M., Ao, H., Taira, Y. (2017). Project Management for ID Projects: Comparative Study on Japan's ODA and ADB Projects in Indonesia. Proceedings of 11th International Conference on Project Management (pp. 279-285).

4. Diallo, A., Thuillier, D. (2004). The success dimensions of international development projects: the perceptions of African project coordinators. International Journal of Project Management, 22(1), 19-31.

5. Yamin, M., Sim, AKS. (2016). Critical success factors for international development projects in Maldices Project teams' perspective. International Journal of Managing Projects in Business, 9(3), 481-504.

6. Ika, LA. (2015). Opening the black box of project management : Does Worls Bank project supervision influence project impact? International Journal of Project Management, 33(5), 1111-1123.

7. Locatelli, G., Mariani, G., Sainati, T., Greco, M. (2017). Corruption in public projects and megaprojects: There is an elephant in the room! International Journal of Project Management, 35(3), 252-268.

8. Ahbab, C., Daneshvar, S., Celik, T. (2019). Cost and Time Management Efficiency Assessment for Large Road Projects Using Data Envelopment Analysis. Teknik Dergi, 30(2), 8937-8959.

9. Verga Matos, P., Romão, M., Miranda Sarmento, J., Abaladas, A. (2019). The adoption of project management methodologies and tools by NGDOs: A mixed methods perspective. Journal of Business Research, 101, 651-659.

10. Golini, R., Kalchschmidt, M., Landoni, P. (2015). Adoption of project management practices: The impact on international development projects of non-governmental organizations. International Journal of Project Management, 33(3), 650-663.

11. Czahajda, R. (2019) Project Management Practices in Polish Nonprofit Organisations. In Z. Wilimowska, L. Borzemski, J. Sviatek (Eds.), Information Systems Architeture and Technology, ISAT 2018, PT III (pp. 358-370). Cham: Springer International Publishing.

12. Ika, L.A., Diallo, A., Thuillier, D. (2012). Critical success factors for World Bank projects: An empirical investigation. International Journal of Project Management, 30(1), 105-116. 
13. Montes-Guerra, M. I., De-Miguel, A. R., Pérez-Ezcurdia, M. A., Gimena, F. N., DíezSilva, H. M. (2015). Project Management in Development Cooperation. NonGovernmental Organizations. Innovar, 25(56), 53-67.

14. Keleckaite, M., Meiliene, E. (2015). The Importance of Project Management Methodologies and Tools in Non-Governmental Organisations. Case of Lithuania and Germany. Fourth International Scientific Conference on Project Management in the Baltic Countries, Project Management Development - Practice and Perspectives (pp. 176-188). Riga: University of Latvia.

15. Ceric, A. (2014). The nemesis of project management: the gaping non-contractual gap. Procedia - Social and Behavioral Sciences, 119, 931-938. 